\title{
HUMAN SECURITY, UNITED NATIONS AND ROHINGYA REFUGEES IN MALAYSIA
}

\begin{abstract}
Aizat Khairi \& Mohd. Na'eim Ajis
${ }^{1}$ lecturer at Student Development Section, Universiti Kuala Lumpur Malaysian Institute of Marine Engineering Technology (UniKL MIMET). Currently, he is also as PhD candidate at Research and Education for Peace Unit (REPUSM), School of Social Sciences, UniversitiSains Malaysia (USM)
\end{abstract}

${ }^{2}$ senior lecturer at School of Government, College of Law, Government and International Studies (COLGIS), Universiti Utara Malaysia (UUM).

\begin{abstract}
Abstrak
Artikel ini menganalisa tentang masalah pengungsi Rohingya yang melarikan diri dari tanah air mereka kerana dinafikan HAM oleh pemerintah Myanmar. Kehidupan sebagai pengungsi tidak aman berbanding dengan komunitas lokal. Mereka harus melarikan diri dari tempat asal demi kelangsungan nyawa. Proses untuk keluar tidak mudah kerana mereka harus menghadapi tantangan baik faktor pemerintah maupun kondisi alam. Malangnya, sesetengah dari pada mereka tidak terselamat dan tewas dalam pergerakan sebagai pengungsi. Walaupun mereka berjaya tiba ke destinasi baru seperti Malaysia untuk memulai kehidupan yang lebih baik, masalah lain pula muncul kerana polis pemerintah Malaysia yang tidak mengiktiraf status pengungsi bagi orang Rohingya. Jadi, masalah yang dihadapi oleh pengungsi Rohingya di Malaysia telah dikaji dari kanta Human Security United Nations Development Programme (UNDP). Hasil analisa menunjukkan bahwa kehidupan seharian pengungsi Rohingya berada di dalam kondisi tidak menentu berdasarkan 7 kategori UNDP. Walau bagaimanapun, kebanyakan Rohingya merasakan bersyukur kerana kehidupan di Malaysia adalah lebih baik dari pada di Myanmar. Walaupun pemerintah tidak mengiktiraf mereka, tetapi pemerintah tidak meletakkan mereka di kem-kemtahanan. Jadi, Rohingya berasa bebas bagi lakukan aktivitas kelangsungan hidup di Malaysia. Inisiatif membantu pengugnsi Rohing ya harus diikhtiarkan supaya mereka mempunyai kehidupan yang lebih baik di Malaysia sementara menunggu pulang ke tempat asal mereka pada masa hadapan.
\end{abstract}

Kata Kunci: Pengungsi Rohingya, UNHCR, UNDP, Pemerintah Malaysia 


\section{Introduction}

Lives as refugees are not easy compare to the others people. They have to run away from their origin place for the sake of lives. Usually the neighborhoods countries will be the place for them to go and they have to cross the border as well. Nevertheless, some of them are not cross the border instead they are stay near to the border. The process to move out is not easy because they have to face a lot of obstacles to make their life's saved. Unfortunately, several of them are not survived and fail to saves their lives ${ }^{1}$.

Mostly, the people become refugees caused by two main factors likes' natural disaster as well as civil wars conflict. For examples, the Achene's people became refugees and went to Malaysia particularly in Penang due to tsunami catastrophe happened in end of 2004. On the other part, some of the Moro's Muslim people had stayed in Sabah, Eastern Malaysia because of intra-state conflict between the Government of Philippines and the Moro National Liberation Front (MNLF) in 1975 until present day. ${ }^{2}$

According to the statement above, the refugees are effect from those factors. But, the most factors that need to be highlight is factor of conflicts. It is because the refugees will become refugees as long the conflict in their area are not getting resolved. The conflict happened not only destroy the human interest but at the same its effect the human security conditions. So this paper focusing about the uncertain life of Rohingya people who are become refugees in Malaysia based on human security perspective.

\section{Literature Review (TinjauanPustaka) \\ a. Refugees}

The United Nations (UN) through the United Nations High Commission for Refugees (UNHCR) defined refugee is an individual or group that had to leave their country of origin. This refers to a situation such as poverty and hardships of the impact of human rights violations, conflict with the government and the civil war in their country. The UNHCR only recognize those who had fled the hardships these eligible refugee status and should be given protection instead of immigrants of a purely economic ${ }^{3}$.

Article 1 of the 1951 Convention relating to Refugees and its 1967 Protocol provide the definition of refugee as well as "an individual or a group is outside the country of his nationality for reasons of cause, are afraid if persecuted by the authorities on the grounds of race, religion, nationality, membership in a social group or political party because of such fear, he cannot or does not want to get protection from the home country"4.

1 Guido, D. \& Waldo, T. Push-Pull Migration Laws. Annals of the Association of American Journal Geographers: Washington. 2005.

${ }^{2}$ KamarulzamanAskandar\&AyesahAbubakar. The Mindanao Conflict. Penang: Southeast Asia Conflict Study Network (SEACSN). 2005.

3 UNHCR.The 1951 Refugees Convention: Question and answers, Geneva: UNHCR Media Relations and Public Information Service. 2003.

${ }^{4}$ http://www.unhcr.se/SE/Protect_refugees/pdf/magazine.pdf. (accessed date 10 March 2016) 
In addition to the 1951 Convention and 1967 Protocol which defines refugees in general terms and broad, there are several other organizations that provide thermal runaway more focused on the situation in a region affected by the refugee problem by the Organization for African Unity Convention (OAU) or Organization for Unity African community in 1969 and the 1984 Cartagena Declaration held in Latin America. Here are the term refugee conventions and declarations pursuant to this as well as:

"The term "refugee" shall also apply to every person who, owing to external aggression, occupation, foreign domination or events seriously disturbing public order in either part or the whole of his country of origin or nationality, is compelled to leave his place of habitual residence in order to seek refuge in another place outside his country of origin or nationality" 5

"...includes among refugees persons who have fled their country because their lives, safety or freedom have been threatened by generalized violence, foreign aggression, internal conflicts, massive violation of human rights or other circumstances which have seriously disturbed public order."6

According to the OAU, a person shall be considered a refugee if he is in a state that has been described above although not suffering from the effects of fear of persecution. These definitions are based on the principle that the need for international protection as a result of a defaulted state protection principles either unwilling or unable to provide protection for the people due to civil war or invasion occurred outside forces. While the Cartagena Declaration of 1984 is to extend the definition of Convention refugee in 1951 and it is the first document adopted in Latin America to refer to the case of the presence of many refugees.

However, in Asia there is the Bangkok Principles that was signed under the Asian-African Legal Consultative Organization (AALCO) in 1966 and revised in 2001. This is to give a more focused definition of refugee problems that hit Asia and Africa in a wider concept. It can also be considered as a supplement to the 1951 Convention, and the OAU and Cartagena Declaration on the refugee's additional argument is "a person who has a well Founded Fear of persecution due to color, ethnic origin and gender"7.

From the argument above clearly shows that it added about aspects of fear as a result of skin color, ethnic origin, gender, and cause them to be persecuted and this would cause them to flee to save themselves. All international conventions and declarations on a show that they are forced to run to the outside is not of their own accord tum external factors such as war, natural disasters, government tyranny, discrimination and others who influence them to act as such.

Through the academic lens, Bahrin and Rachangan see a political refugee because their movements involving the political boundaries of a country, and

${ }^{5}$ Organization for African Unity Convention (OAU) or Organization for the People of African Unity was established to look at particular aspects of refugee problems in Africa. Founded on 10 September 1969 and came into force on 20 June 1974.

${ }^{6}$ United Nations High Commissioner for Refugees. Cartagena Declaration on Refugees, Colloquium on the International Protection of Refugees in Central America, Mexico and Panama, Article III (para, 3). 1984

7 Asian-African Legal Consultative Organization (AALCO). "Final Text of the AALCO's 1966 Bangkok Principles on Status and Treatment of Refugees" 24 June 2001 di AALCO 40, New Delhi, Article III (para. 3). 
sometimes their movement of more than one country. Typically, they move in a crowded with numbers 8 . Shoesmith defines refugees as "people who are involuntary and fairly abruptly obliged to quit Their Homes and seek Asylum from economic and environmental calamities as well as political."9 The factors that forced them to flee not only from the economic and environmental issues, but the main factors contributing to the occurrence of these refugees are due to the origin of the conflict situation itself ${ }^{10}$.

\section{b. Human Security United Nations Development Programme (UNDP)}

Wishes and dreams to create a human-centric security concepts in the Human Development Report 1993 successfully realized in the Human Development Report 1994 and it has been a catalyst idea of human security official to the world in order to defines it based on values, interests and needs and understanding for safety idea raised human security encompasses such a broad definition of employment, health, food, environmental, political, human rights, and education ${ }^{11}$.

Human Development Report 1994 was presented by Dr. Mahbub-ul-Haq who was the Special Adviser to the governing body Development Programme of the UN and a former Finance Minister of Pakistan in a conference of the United Nations Development Programme (UNDP). He pointed out the concept of security because there are two big issues of the world that require all parties think the solution together again after the Second World War how prevent the occurrence of another war and efforts to avoid crisis and ensure economic downturn economic progress can be felt by all ${ }^{12}$. Previously reported in the UNDP report, Dr. UlHaq has participated in several conferences on issues such as security, and economic development as North South Roundtable titled Economics of Peace in Costa Rica in January 199013. As a result of the conference was successful in identifying the challenges to be faced in the post-Cold War era as the need for reduction of military influence, to ensure economic and environmental as well as find ways to deal with the impact of globalization ${ }^{14}$.

\section{c. UNDP Human security as a Broad Concept}

Dr. UlHaq presented the Report of the Human Development 1994 the UNDP program and he also wants to attract the attention of representatives of the international who attended the United Nation's 1995 World Summit on Social

${ }^{8}$ Bahrin and Rachangan were the academic staff of the University of Malaya, Kuala Lumpur. They were the earliest local academic researchers focused on the study of refugees in Malaysia from the perspective of policy and law. Their findings and writing of pioneering academic circles who want to do research in the field of refugees in Malaysia.

${ }^{9}$ Dennis, S. Refugees and Regional Politics: The Dynamics of Refugees Flows in Mainland Southeast. UK. 2000. Asia". http://www.ntu.edu.au/faculties/Iba/schools/Law?apl/ Retreating/shoesmith.htm (accessed date 10 March 2016).

10UNHCR. The 1951 Refugee Convention: Question and answers, Geneva: UNHCR Media Relations and Public Information Service. 2003.

${ }^{11}$ Paul, H.Human Security and East Asia: In the Beginning. Journal of East Asia Studies. Singapore. 2004. Pp. 263-284. 1995.

${ }^{12}$ Mahbub, ul H. Reflection on Human Development. Oxford: Oxford University Press.

${ }^{13}$ Ibid,.

${ }^{14}$ UNDP. Human Development Report. New York: Oxford University Press. 1994. 
Development in Copenhagen, Norway to the concept of human security has been accepted by all parties and can be implemented in policy a country ${ }^{15}$. In his speech, he interprets the concept of Human Security as:

"Human security is not just security of land, it is security of people, it is not just security through arms, it is security through development, is not just security of nations, it is security of individuals in their home and their jobs, is not just a defense against conflict between nations, it is defense against conflicts between people." 16

However, the 1994 UNDP Human Development Report states the concept of human security more carefully and systematically, namely:

"Human security can be said to have two main aspects. It means, first, safety from such chronic threats as hunger, disease and repression. And second, it means protection from sudden and hurtful disruptions in the patterns of daily life-whether in homes, in jobs or in communities. Such threats can exist at all level of national income and development."17

To understand the concept of human security in depth UNDP, Human Development Report 1994 states:

"Human security means that children will not die, disease will not transmit, jobs will not lose, communal tensions will not translate into conflict violence and dissenters will not be forced to silence."18

Based on the above definitions, it can be understood that the concept of UNDP's human security is broad andthis shows that the security can be translated to different forms and exists in a variety of situations. Not only based security threats as well as threats of war but a very large impact on human life such as hunger and famine, poverty, chronic and infectious disease, and oppression. This coincided with a speech by former UN Secretary General, Kofi Annan, who said the concept of human security should be interpreted in a broader purpose:

"Human security can no longer be narrowly defined as the absence of armed conflict, be it between or within states. Gross abuse of human rights, the large-scale displacement of civilian populations, international terrorism, the AIDS pandemic, drug and arms trafficking and environmental disasters present a direct threat to human security, forcing us to adopt a much more coordinated approach to a range issues"19.

There are four main features in the UNDP human security concept; the first one is the universality of every nation in the world is not about strong or weak, and every person whether rich or poor all have an impact on human security. Although different human security threats based on reasons that occur from one region to another, but they influence each other. Secondly, the nature of interdependence each of the categories found in the concept of Human Security. For example, if there is a man who threatened his safety, it will affect other people around the world. Take the example of

15 In an effort to highlight and promote the concept of human security, Dr. UlHaq have got help and support from Dr. Amartya Sen, a professor of economics and also a Nobel prize winner in economics in 1998.

${ }^{16}$ Mahbub, ul H. A New Framework for Development Cooperation. United Nations Chronicle, Vol. 10, (4). 1993. P. 42.

17 UNDP. 1994., op.cit,

18 UNDP. 1994.,op.cit, Pp. 22-24.

19 Kofi, A. Report of the Secretary-General on the Work of the Organization. Official Record of the General Assembly, 55th Session of the additional No.1 (A/55/1). New York: UN. 2000. P. 4. 
the problems of hunger, disease, drug trafficking and ethnic conflict will involve more than one race in the world. Thirdly, is the early prevention is better than prevention of late made such efforts to prevent the spread of AIDS. Fourthly, human safety is based on the human itself because human security is about the human condition who live and socialize in the community either in peace or conflict, freedom of choice and the potential to influence the market and society ${ }^{20}$.

As a result of four main features in the UNDP human security concept, it had focused on seven different categories of economic security ${ }^{21}$, food security 22 , health security ${ }^{23}$, environmental security ${ }^{24}$, individual security ${ }^{25}$, community security ${ }^{26}$ and

${ }^{20}$ UNDP. 1994.,op.cit, Pp. 22-23.

${ }^{21}$ Economic security requires an individual security on a revenue base of their efforts are productive and profitable or have access to other income. Today, however, only about a quarter-million people in the world can be considered to have a guaranteed income. Although the problem may be more serious economic security in developing countries, attention should also be given to the developed countries are also facing the same problem. Unemployment as a result of economic problems be an important factor to the problem of political pressure and ethnic violence. UNDP. 1994., Op.cit,.

${ }^{22}$ Food security also requires that all humans have always had access to the physical and economic to source food. According to the UN, as a whole whether or not the food there is not a problem, but the main problem is the unbalanced distribution of food and lack of power to purchase food items. Previously, the problem of food security became an issue in the national and global level. However, the impact is limited and according to the United Nations, the key to this problem is to find the relationship between the means for access to property, employment and income security, and these criteria have a relationship with economic security. UNDP. 1994., Op.cit,.

${ }^{23}$ Health security or health assurance aims to ensure minimum protection from diseases and plagues and unhealthy lifestyle. In developing countries, the main problem that caused the death was caused by infectious and parasitic diseases, while in industrialized countries they are the main killer diseases caused by circulatory system. Today, the lifestyle associated with chronic diseases being the leading killer of the world community, with $80 \%$ of the deaths result from chronic disease occur in countries with low and middle income. According to the UN, developing countries and the industry is exposed to security threats and eventually health among the poor, especially children living in remote areas. This leads to an unbalanced diet due to lack of access to health services, clean water and other basic needs. UNDP. 1994., Op.cit,.

${ }^{24}$ Environmental security aims to protect people from short and long-term damage, the threat of human action and environmental pollution. In developing countries the greatest threats in the security environment is the lack of access to clean water sources. For industrialized countries are facing the threat of air pollution and global warming effects of greenhouse gas emissions. UNDP. 1994., Op.cit,

${ }^{25}$ Individual or personal security aims to defend an individual from physical violence either from within the country or abroad, from the tyranny of the individual to the state actor sub enforcement agencies such as the police and also from internal abuse by adults. Typically for all individuals, factors of an individual security threat comes from criminal cases facing them, particularly in the brutal and violent crime. UNDP. 1994., Op.cit,

${ }^{26}$ Community or public security aims to protect a community from the loss of values in community customs, and culture and identity that has long existed. In addition, it also seeks to curb violence arising from inter-ethnic conflict. Typically, a minority community in a country will be exposed to the threat of ethnic conflict ethnic majority. About half the countries in the 
political security ${ }^{27}$. Features and the categories found in the UNDP human security concept is to meet its goal of which is divided into two parts, namely freedom from fear and freedom from want 28 . Two main parts have been identified since the establishment of the United Nations and the other alleged freedom from fear more dominant than the second part which is based on the lack of freedom of international relations issues that take place during and after the Cold War see countries often trapped in the midst of war. However, countries that founded the UN was trying to consider the issue of regional security and human justice. This can be seen by the U.S. Secretary speech at the San Francisco conference that established the United Nations:

"The battle of peace has to be fought on two fronts. The first is the security front where victory spells freedom from fear. The second is the economic and social front where victory means freedom from want. Only victory on both front can assure the world of an enduring peace.....No provisions that can be written into the Charter will enable the Security Council to make the world secure from war if men and women have no security in their homes and their jobs." 29

Freedom from fear and freedom from deficiencies adopted by UNDP human security concept is based on the speech also former U.S. President Franklin Delano Roosevelt on January 6,1941, known as Freedom of Speech 4:

"In the future days, which we seek to make sure, secure, we look forward to a world founded upon four essential human freedoms. The first is freedom of speech and expression-everywhere in the world. The second is freedom of every person to worship God in his own way-everywhere in the world. The third is freedom from want-which, translated into world terms, means economic understandings which will secure to every nation a healthy peacetime life for its inhabitants-everywhere in the world. The fourth is freedom from fear-which, translated into world terms, mean a world-wide reduction of armaments to such a point and in such a through fashion that no nation will be in a position to commit an act of physical aggression against any neighbor-anywhere in the world. That is no vision of a distant millennium. It is definite basis for a kind of world attainable in our own time and generation. That kind of world is the very antithesis of

world had to face inter-ethnic conflict in the country. The UN has declared the year 1993 is the Year of Indigenous People to describe hardship and suffering 300 million indigenous people in 70 countries are faced with the situation of violence and ethnic discrimination. UNDP. 1994., Op.cit,

${ }^{27}$ Political Security takes care and seek to identify whether an individual about living in a society that has basic human rights in their lives or otherwise. According to a survey conducted by Amnesty International, political pressure, and the planned elimination of torture is still practiced in secret again in 110 countries of the world. Human rights violations often occur in the event of political unrest in the country. With the press and put pressure on certain individuals and groups, the government as the government is able to control the information and thinking in certain circumstances to erode them. UNDP. 1994., Op.cit,

${ }^{28}$ Freedom from want of the final goal to achieve in the concept of Human Security as well as freedom from fear. Freedom of lack of reference to the efforts to improve human life in various ways such as increased income, upgraded economy, business and employment opportunities and improve individual skills. All these approaches are related to the concept of Human Development.

29 UNDP. 1994.,op.cit, P. 24. 
the so-called new order of tyranny which the dictators seek to create with the crash of a bom." 30

So it can be understood that freedom from fear is the effort to protect people from violent conflict not directly related to issues such as poverty, injustice and weakness of the government in completing it. Therefore, should the approach as conflict prevention and resolution and peace-building in order to address this problem. Freedom of lack sees greater threats such as famine, economic crisis, currency collapse, disease and natural disasters affecting human security itself ${ }^{31}$.

The concept of human security in the limelight of the world when the United Nations under the UNDP agency has drawn up a framework on the issue of security is not just revolve about war and national defense, but safety should also focus on the human. This is because if human security is threatened, indirectly it will threaten the security of the country and thus have an impact on regional and global stability. Therefore, it is described that the human security aspects are actually devoted to advancing the quality of human life from the country. In short, if human security compromised then it could pose a threat to national security ${ }^{32}$.

\section{Finding and Discussion}

\section{a. Rohingyas in Myanmar}

The origin of Rohingyas people were from Myanmar. Most of them live in Rakhine's State located in Western Myanmar. This area is sharing the border with Bangladesh. According to the history, the Rohingyas embraces Islam because of trade's activity on $9^{\text {th }}$ century in Rakhine while Arab's trader anchored. Then, they did the business activities and at the same time married the local people there. The Rohingyas local language it's almost similar with Bangladeshi language because of migration activities long time ago and some believe the Rohingyas were from Bangladesh. That is why the government of Myanmar not recognizes them as a part of Myanmar's citizenship ${ }^{33}$.

\section{b. Why the Rohingyas Becomes Refugees?}

The main reason that turns the Rohingyas as Refugees was the factor of act citizenship. From the Foreigner's Act 1864 until Myanmar's Law Citizenship 1982, there were no any kinds of act that recognize and protect the Rohingyas in Myanmar. This situation makes the Rohingyas as stateless person. Moreover, the situation is getting worst when the junta launched the coup de etat from the civil governance and created the martial law in 1962. The junta rule under the Jeneral Ne Win forced the Rohingyas left out of the country because most of them failed to prove they are Burmese. So, the first exodus happened in 1977 when almost 200,000 people, mostly

\footnotetext{
${ }^{30}$ Excerpts from a speech Franklin Delano Roosevelt during the General Assembly of the United States Congress, January 6, 1941.www.kentlaw.edu/faculty/.../ 4THEFOURFREEDOMSSPEECH.pdf (accessed date 15 April 2016)

31 Human Security Centre. "What is Human Security." http://www.humansecurityreport.info/index.php?option=content\&task=view\&id=24\&itemid =59(accessed date 20 April 2016).

32Zarina, O.PolitikdanKeselamatan. Bangi: PenerbitUniversitiKebangsaan Malaysia. 2005, Pp. 17-20.
}

${ }^{33}$ Abu, T. A. Sejarah Myanmar. Kuala Lumpur: Dewan Bahasa danPustaka. 2000, P. 34. 
the Rohingya leave their place when the junta launched the Naga Min operations to redefine the Burmese ${ }^{34}$.

In the middle of year 1991, the second exodus happened when almost 250,000 Rohingyas went to Bangladesh because of the human right violations from the junta. The recent Myanmar Law Citizenship created in 1982 was against the international law citizenship because the junta declared the 135 ethnic in Myanmar as their citizenship, except Rohingyas ${ }^{35}$. The junta named the title of The State Peace and Development Council(SPDC) not recognized Rohingyas as a statement:

"In actual fact, although there are (135) national races living in Myanmar today, the so-called Rohingya people are not one of them. Historically, there has never been a "Rohingya" race in Myanmar. The very name Rohingya is a creation of a group of insurgents in the Rakhine State. Since the First Anglo-Myanmar War in 1824, people of Muslim Faith form the adjacent country illegally entered Myanmar Ngain-Ngan, particularly Rakhine State. Being illegal immigrants they do not hold immigration papers like other national of the country." 36

The SPDC response to the questioned of the United Nations' Committee on the Rights of Children on April 2004 related Rohingya issue of citizenship:

"The Governments renders full of equal treatment to these people, as with other races, in matters relating birth and death registration, education, health and social affairs. In the official records, they listed as Bengali racial group of the Bengali race and are recognized as permanents residents within Myanmar." 37

\section{c. The Rohingyas Moved to Malaysia}

There is no exact record about the arrival Rohingyas refugees in Malaysia. But, according to the several interviews from the Rohingyas who are settled in Malaysia, they told that most of them went to Malaysia in period of 1991, during the second exodus. The Rohingyas refugees came into Malaysia through three ways. Firstly, is by the flight. They went to the Bengal Sea to cross the border from Maungdaw (Myanmar) to Teknaf (Bangladesh) by boat. Then, meet the Bangladeshi agent and pay them to make a fake Bangladeshi passport and book a flight ticket to Malaysia ${ }^{38}$.

Secondly is by crossing the border through the land route. The Rohingyas have to pay the Burmese agent for sending them to Malaysia. Usually, the agent will gather the Rohingyas who want to go to Malaysia at Yangon (Rangoon), Myanmar's Capital City. Then, the will bring the Rohingyas until the border of Thailand-Malaysia at Bukit KayuHitam by van or car. The travel it's about one until two weeks. When they made

34 Martin, S. Burma: Insurgency and the Politics of Ethnicity. Dhaka: Dhaka University Press. 1999.

${ }^{35}$ Médecins, S. F. 10 Years for the Rohingya Refugees In Bangladesh: Past, Present and Future. Holland: MédecinsSansFrontières Press. 2002. P. 10.

36 Press release from the Ministry of Foreign Affairs, Union of Myanmar on February 26, 1992. See also: Political Situation of Myanmar and its Role in the Region, Col. Hla Min. Office of Strategic Research, the Union of Myanmar Ministry of Defense, February 2001. Pp. 95-99

37These questions posed by the Committee on the Rights of Children of the United Nations Association of the SPDC is because Myanmar is a member of the Convention on the Rights of the Child and the answer has been sent to the committee in April 2004.

38 Interviews with Rohingya refugees named Anwar, held at UniversitiSains Malaysia on July 6, 2015. 
to cross to Malaysia, the other agent will bring them to northern state of Malaysia for instances, Kedah or Penang and the Rohingyas can make a new life in here ${ }^{39}$.

Thirdly is by the sea route. The Rohingyas make a collection between of them to buy a boat and hire an agent to bring them to Malaysia. This way is the toughest because they have to struggle during the voyage to Malaysia. The travel takes a lot of time and amount of them are beyond the boat capacity. So the travel always in risky because of uncertain weather likes big waves and storm. At the same time, they have to share the food and water among themselves ${ }^{40}$.

\section{d. The Rohingyas in Malaysia from The Human Security United Nations Development Programme (UNDP) Perspectives}

The Rohingyas refugees thought that they will get a better life when they move to another place, particularly Malaysia. It is because Malaysia as a well-known country that have a lot of economic opportunity and prosperity. Unfortunately, life in Malaysia is not easy as well because of the government of Malaysia policy do not recognize the status of refugees. So, the local authority will assume the Rohingyas and others refugees as illegal immigrant. If get caught, the authority will send them back to their country and the life of the Rohingyas will be in a risk again for sure. Apparently, the daily lives of Rohingyas are in uncertain and this situation will be discussed throughout the Human Security UNDP perspectives. Human Security UNDP promotes the 7 of category security that need to be focus in order to protect the life of human being and empower the development of economy. From the 7 categories, Human Security UNDP aim to achieve the last goal that is freedom from fear and freedom from want.

\section{i. Economic Security}

Economic security is referring to a job guarantee. From the job, the people can gain a salary or money so that they can support their daily life. But, the Rohingyas in Malaysia can be take part in informal sector only likes this statement "Refugees who are waiting to be resettled to third countries are not allowed to work but can take on odd-jobs" 41 . At the moment, the Rohingyas were not allowed to work. After the UNHCR has a discussed with the government, the result shows that the Rohingyas have allowed to work but in informal sector only likes cleaning, garbage collector, and market assistants 42 .

${ }^{39}$ Interview with UNHCR Liaison Officer at UNHCR Malaysia in Kuala Lumpur on 22 April 2011.

${ }^{40}$ Interview with Dr. Che Mohd Aziz, a senior lecturer at Universiti Utara Malaysia who is also doing research on refugees in Malaysia, on July 12, 2015.

41 Malaysia local newspaper, The Star. http:/ / thestar.com.my/news/story.asp?file=/2010/2/21/nation/20100221173332\&sec=nation( accessed date 13 March 2016).

${ }^{42}$ Government may allow refugees to work http://thestar.com.my/news/story.asp?file=/2010/2/22/nation/5692963\&sec=nation (Accessed date 13 March 2016). 


\section{ii. Food Security}

Food security it's related to the economic security because it involve human capability to the access of the food resources, work. From the experience of Rohingyas while they work in informal sector, it will affect the income that they get because there is not a guarantee for Rohingyas to get same income on the next day. If they get some trouble on their work, they cannot get the income on that day and it will be a problem to their daily life. So, the unguaranteed income will affect to the food security for them ${ }^{43}$.

\section{iii. Health Security}

Previously, the Rohingyas and others refugees need to pay a medical treatment when they go to the government hospital and clinic. The payment is standards to the foreigners that are RM 15.00 for basic illness. But, the other cost of treatment likes operations and giving birth is difference and it is more expensive. A few years ago, the government given the $50 \%$ discount for those refugees who can shows their UNHCR card to the hospital officer. But some of the Rohingyas are not effort to pay it even the cost is cheaper. So, they just buy the medicine from the pharmacy rather go to the hospital. ${ }^{4}$

\section{iv. Environmental Security}

This security is regards to the Rohingyas Refugees living place. Both government and UNHCR not provide the shelter although the authorities allow them to stay in Malaysia for temporary period. So the Rohingyas have to find it by themselves. Usually, the Rohingyas will share the living place with other family members. So they can save the cost. Some of them rent a small and cheap flats and some prefers to stay in squatters' area. If the environments are not really clean and smelly, for them it is not a big problem as long as they have a shelter. ${ }^{45}$

\section{v. Personal Security}

Some of the Rohingyas refugees given the UNHCR card as a temporary status from UNHCR office based in Kuala Lumpur, Malaysia. With this card, the Rohingyas and others refugees be allowed to stay in Malaysia temporarily. They will not be arrested when the authorities launch operations to arrest illegal immigrant as long they can shows this card. But, at the same time this is not a guarantee even the Rohingyas have these card because some authority will take and vantage from their situation to make money. The Rohingyas need to pay certain amount otherwise they will be arrested or their UNHCR card being throw away ${ }^{46}$.

${ }^{43}$ Interviews with Mr Kader, a member of the Rohingya Society in Malaysia (RSM) RSM headquarters located in Ampang, Selangor on August 18, 2015.

${ }^{44}$ AzizahKassim. Muslim Refugees in Malaysia: An Analysis of the Status of Rohingya from Myanmar. ISEA Workshop on Muslims in Southeast Asia, organized by Institute for Language and Cultures of Southeast Asia (ILCAA). Tokyo: Tokyo University of Foreign Studies. 2010.

${ }^{45}$ Interviews with Mr Ghani, Deputy President Rohingya Society in Malaysia (RSM) RSM headquarters located in Ampang, Selangor on August 18, 2015.

46 Interview with Mr. Anwar, the General Secretary of the Rohingya Society in Malaysia (RSM) RSM headquarters branch located in Penang, Gelugor on July 8, 2015. 


\section{vi. Community Security}

Many Rohingyas says that lives in Malaysia better than the origin place. It is because they can do whatever they want as long they not break the Malaysia's law. As Muslims, it is not a problem to do religious activities likes praying and fasting because Malaysia is a Muslim country, majority Malaysian are Muslim and Islam is the official religion ${ }^{47}$. That is why the Rohingyas makes Malaysia as their destinations to stay lives. Currently, there is not conflict tragedy happened between the Rohingyas and the locals except small dispute cases between Rohingyas and Indian people because of several factors likes job and living place ${ }^{48}$.

\section{vii. Political Security}

When discussing about political security Rohingyas refugees, it's a dilemma for the government. It is because even the UNHCR recognized and give them the UNHCR card, but the Malaysia's policy still considered them as illegal immigrant. They government has their own reasons that if they recognized the refugees in Malaysia, it will be open the flood gate to others refugees to come to Malaysia. At the same time, the government has to protect them and give the same standard procedure like locals. Nevertheless, the government still be tolerate with the refugees in Malaysia and has a negotiation discussion with the UNHCR from time to time. ${ }^{49}$

\section{Conclusion}

As refugees in Malaysia, the Rohingyas' lives are not so easy compare to the locals. Their every day's life still in uncertainty even though they already being settle down in this country for many years. But, at the same time most the Rohingyas do feel grateful because the lives in Malaysia better than in Myanmar. Although the government does not recognized them, but the government not put them in detention camps. So, the Rohingyas feel free to do to keep their survival in Malaysia. They hope can go back to their place of origin. Unfortunately, as long the Myanmar's government not declares them as citizen, the rights of Rohingyasare being denied. So they cannot go back otherwise, their human security's condition will be violated by the rulers there. The initiatives need to be finding is to help the Rohingyas have a better life for their children in future so the stateless status can be change at last.

\section{References}

Abdurasad (1978) Moros Not Filipinos. Manila: AIP Printshop.

Amnesty International (2009) Hidup dalam Bayang-bayang, Primer tentang Hak Asasi Manusia Migran. Kuala Lumpur: Amnesty International Publications.

47 Interview with Mrs. Norazrina and Mr. Adnan Ahmad, staff at UniversitiSains Malaysia. They are a local residents who has lived long in Penang. December 11, 2015.

48 Interview with President Rohingya Society in Malaysia (RSM), Mr. Hamid held at UniversitiSains Malaysia on July 6, 2015.

49 Interview with National Security Council officials who have specialized on the issue of refugees in Malaysia located at Putrajaya, Federal Government Administrative Centre on June 2, 2011. 
Amnesty International (2010) Abused and Abandoned: Refugees Denied Rights in Malaysia. UK: Amnesty International Publication.

Appadorai, A. (1968) The substance of Politics, edisi ke-10. Madras: Oxford University Press.

Abd. Rahman Embong (2006) PeranandanOrientasiSainsSosial Malaysia. Bangi: UniversitiKebangsaan Malaysia.

Asreemoro (2007) Tausug and the Sulu Sultane. Selangor: RNH Marketing Sdn. Bhd.

AzizahKassim (2010) Muslim Refugees in Malaysia: An Analysis of the Status of Rohingya from Myanmar. ISEA Workshop on Muslims in Southeast Asia, organized by Institute for Language and Cultures of Southeast Asia (ILCAA). Tokyo: Tokyo University of Foreign Studies.

AzizahKassim\&UbongImang (2005) Orang Pelarian di Sabah : Status danProspekdalamjurnalState Responses to the Presence and Employment of Foreign Workers in Sabah. Kota Kinabalu: Universiti Malaysia Sabah.

Bahrin\&Rachagan (1984) The Status of Displaced Filipinos in Sabah: Some Policy Considerations and Their Long Term Implications. Singapura: InstitutKajian Asia Tenggara.

Buzan, B. (2001). Human Security in International Perspective. Kuala Lumpur: Institute of Strategic and International Studies.

Cesar AdibMajul (1985) The Contemporary Muslim Movement In The Philippines. Berkeley: Mizan Press.

Cesar AdibMajul (1988) Islam di Filipina. Kuala Lumpur: Dewan Bahasa danPustaka.

Che Man, W. K. (1990) Muslim Separatism: The Moros of Southern Phillippines and the Malays of Southern Thailand. Singapore: Oxford University Press.

Debiel, T. \&Sascha, W. (2006) Human security on foreign policy agendas: changes, concepts and cases (Duisburg, Germany: Institute for Development and Peace, INEF. German: University of Duisburg-Essen.

Dennis, S. (2005), Refugees and Regional Politics: The Dynamics of Refugees Flows in Mainland Southeast Asia".London: Routledge.

Howard, A. (2001) From Refugees to Forced Migration: The UNHCR and Human Security. New York: Centre for Migration Studies of New York, York University.

International Law Book Services. (2003) AktaImigresen 1959/63 (Akta 155) EperaturanperaturandanAktaPasport 1966 (Akta 150) : (hingga 20hb Mei 2003) / disusunolehLembagaPenyelidikanUndang-Undang. Petaling Jaya: International Law Book Services. 
Isidro, A. (1968). Muslim Philippines. Mindanao: University Research Center Mindanao State University.

KamarulzamanAskandar\&AyesahAbubakar (2005) The Mindanao Conflict, Penang: Southeast Asia Conflict Study Network (SEACSN).

MahbubulHaq (1995). Reflection on Human Development. UK: Oxford University Press.

MahbubulHaq (1993) A New Framework for Development Cooperation. US: United Nations.

UNDP (1993) Human Development Report 1993. New York: Oxford University Press.

UNDP (1994) Human Development Report1994. New York: Oxford University Press.

UNHCR (2001) BukuPanduanUndang-undangAntarabangsaBagi Orang Pelarian. Kuala Lumpur: UNHCR Malaysia.

UNHCR. (2003) The 1951 Refugees Convention: Question and answers. Geneva: UNHCR Media Relations and Public Information Service. 